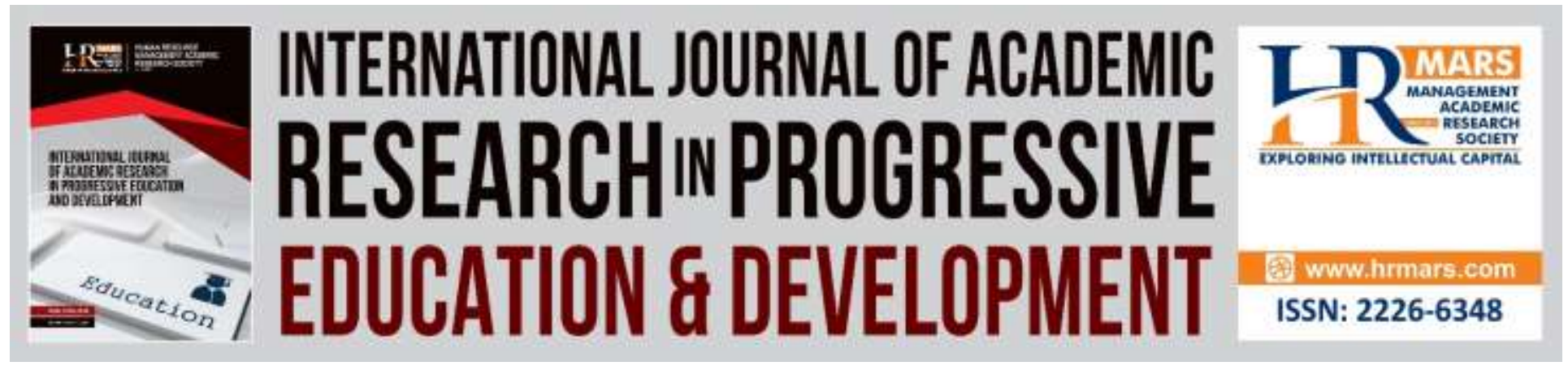

\title{
The Importance of Technological Pedagogical Content Knowledge In Teaching Reading Skills
}

\author{
Musrifah Sarjoni, Fadzilah Abd Rahman, Azhar Md. Sabil and Masnida Md. \\ Khambari
}

To Link this Article: http://dx.doi.org/10.6007/IJARPED/v8-i4/6904

DOI:10.6007/IJARPED/v8-i4/6904

Received: 10 November 2019, Revised: 30 November 2019, Accepted: 11 December 2019

Published Online: 31 December 2019

In-Text Citation: (Sarjoni et al., 2019)

To Cite this Article: Sarjoni, M., Rahman, F. A., Sabil, A. M., \& Masnida Md. Khambari. (2019). The importance of Technological Pedagogical Content Knowledge In Teaching Reading Skills. International Journal of Academic Research in Progressive Education and Development, 8(4), 1053-1062.

Copyright: (C) 2019 The Author(s)

Published by Human Resource Management Academic Research Society (www.hrmars.com)

This article is published under the Creative Commons Attribution (CC BY 4.0) license. Anyone may reproduce, distribute, translate and create derivative works of this article (for both commercial and non-commercial purposes), subject to full attribution to the original publication and authors. The full terms of this license may be seen

at: http://creativecommons.org/licences/by/4.0/legalcode

Vol. 8(4) 2019, Pg. 1053 - 1062

http://hrmars.com/index.php/pages/detail/IJARPED

JOURNAL HOMEPAGE

Full Terms \& Conditions of access and use can be found at http://hrmars.com/index.php/pages/detail/publication-ethics 


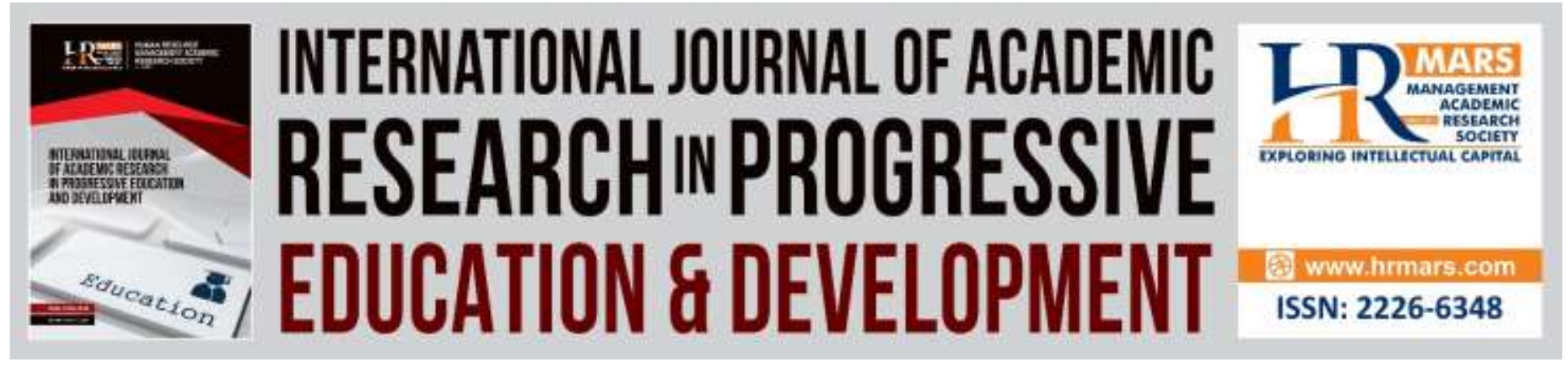

\title{
The Importance of Technological Pedagogical Content Knowledge in Teaching Reading Skills
}

\author{
Musrifah Sarjoni, Fadzilah Abd Rahman, Azhar Md. Sabil \\ and Masnida Md. Khambari
}

Faculty of Educational Studies, University Putra Malaysia, 43400 UPM, Serdang, Selangor Darul

Ehsan, Malaysia.

\begin{abstract}
Nowadays, Malay Language is a medium of instruction at primary, secondary and tertiary levels in Malaysia education system. In learning and teaching of Malay Language, students need to master reading skills since elementary school. The Technological Pedagogical Content Knowledge (TPCK) is best applied in the study of reading skills. Teachers need to master the TPCK in order to create an effective learning environment which more fun and engaging to enhance the creativity, innovation and stimulation of students. Information and Disclosure of Experiences related to TPCK in reading skills is essential and necessary as reference material for the relevant parties.

Keywords: Technological Pedagogical Content Knowledge (TPCK), Effective Learning, Reading Skills and Education.

\section{Introduction}

Reading skills is one of the components in teaching and learning of Malay Language as stated in the curriculum of schools in Malaysia. Reading is very important in the process of enhancing knowledge and improving the quality of one's learning. The minds and knowledge of people who are constantly reading will grow, more open and understanding. According to Tamam, Zamri, Nik Mohd. Rahimi, \& Jamaluddin (2010); Yahya \& Maszuraimah (2013), a study on reading processes is important to help students in increasing their knowledge. Reading also can develop knowledgeable and insightful generation. Therefore, literate society can make knowledge as a living platform.
\end{abstract}

Technological Pedagogical Content Knowledge (TPCK) is a theory design which has been introduced by (Koehler \& Mishra, 2009). Basically, TPCK is knowledge of technology-related technology integration that must be balanced between content knowledge, pedagogical knowledge, and technology knowledge. The idea is derived from the concept of Content Pedagogical Knowledge (PCK) by Lee Shulman in year 1986 (Hashweh, 2014). Knowledge Relations Content pedagogy technology also best used in language teaching because of its uniqueness. 


\section{Reading Skills in Education}

Reading is a power to interpret and translate letters, words, and sentences into meaning (Serravallo, 2015). Meanwhile, Beers \& Probst, (2012) and Beltramo \& Stillman, (2015) have stated that there is a difference between speaking and reading, which speaking is the ability to hear words and reading is the ability to understand words. If reader only says the word, it is not considered to read completely until he or she understands what it is. Once a reader can translate the word into meaning, it is considered a reading (Nelson, 2019).

Implementation of teaching under the Primary School Curriculum (KSSR) is a benchmark of $21^{\text {st }}$ century education effectiveness as envisaged by the Ministry of Education since 2014, which in line with the transformation of national education stated in the Malaysia Education Development Plan (2014-2025). The Education Ministry has positioned internet as important medium to aid knowledge exploration in the era of information-based information explosion.

Hence, teachers play a huge role to improve students' language skills. According to Wong \& Nur Ain Elzira, (2018) language skills is fundamental and must be emphasized during the process of learning and facilitating (PdPc) in the classroom. As a curriculum implementation agent, teachers need to be concerned with the objectives of current curriculum to enable the ministry of education to achieve its goals in educating the students with technology. This is line with The National Education Philosophy (FPK) aims to develop students' individual potential of students as a whole and integrated physically, emotionally, spiritually and intellectually.

In language teaching and learning, listening, speaking, reading, and writing are skills that must be practiced (Kern, 2006). But, cross-curricular skills also have been emphasized in the Primary School Curriculum (KSSR) to enhance students' knowledge and self-esteem. The use of information technology is one of the cross-curricular skills that has been applied in the teaching of Malay language (Ministry of Education, 2015). In order with that, Malaysia Education Development Plan 2015-2025 has outlined three waves of Information and Communications Technology (ICT) in education. The First Wave (2013-2015) is to enhance the ICT base, where efforts are made to ensure that the basic ICT infrastructure and competencies are always available throughout the system, and do not tied to any specific technology platform. This is to ensure that students and teachers have adequate access to ICT equipment, provide education system with sufficient learning platforms, and broadband networks and all teachers are competent in ICT (Radha, Noorizah, Kemboja, \& Shahirah, 2017). Meanwhile, the Second Wave (2016 -2020) is introduction of innovation in ICT.

The basis of innovation in education must be emphasized in shaping a progressive and innovative education system to drive change and progress (Noraini, Hani, Mahizer, Mohd, \& Norazilawati, 2013). Innovation in education only succeeds if teachers are skilled and able to use the application in the teaching and learning process (PdPC). ICT is important to support teaching innovation. This issue has been explained through several other studies, so more attention is given to the role of teachers in technology integration, but technological knowledge alone is not sufficient to enable a teacher to master technology integration in the learning environment 
(Abbitt, 2011; Eady \& Lockyer, 2013; Ozudogru, 2019). The 2013-2025 PPPM clearly states that Malaysia Ministry of Education (KPM) is exploring a range of innovations, particularly in terms of distance learning and self-directed learning that can be used to expand access to high quality teaching irrespective of the skill level or location of students. To address innovation in teaching and learning, teachers need to master the ever-changing technology and improve their knowledge. Teachers also need to practice culture such as reading and thinking during the PdPc proces (Yahya \& Lailinanita, 2012).

\section{Technological Pedagogical of Content Knowledge (TPKC)}

Technological Pedagogical Content Knowledge (TPCK) has been introduced by Mishra and Koehler (2006) based on the idea of content pedagogical content knowledge (PPK) by Shulman (1986). The PPK model introduced by Shulman (1986) has a component of content pedagogy and he stated that the content of a subject cannot be separated from pedagogy. Shulman, (1986) also emphasized that teachers need to master knowledge related to the subject matter and have pedagogical skills. Pedagogical components are the process and method of teaching and learning, while content component is the content of the subject in the syllabus which being taught or learned (Eady \& Lockyer, 2013).

Mishra and Matthew J. Koehler is the developer of PTPK framework (Mishra \& Koehler, 2006). This theoretical framework involves three types of knowledge namely technology, pedagogy and content. All three knowledges are combined and formed a new knowledge which is content pedagogical technology (PTPK) knowledge. The basis for effective teaching by using technology requires the teacher's understanding to use appropriate technology, approaches and teaching techniques to convey the content of the lesson as well as students' existing knowledge. Researchers such as Aguinaldo, (2012); Atasoy \& Aygun, (2016); Cherner \& Smith, (2017); Norhiza, Zamri, \& Wan Muna Razana, (2016) and; Papanikolaou, Makri, \& Roussos, (2017) have been argued that PTPK strives to address the complex nature, form, and knowledge of teachers involving content knowledge, pedagogy, and technology.

As a conclusion, there are seven constructs in the PTPK framework results from the complex interaction between three main knowledge constructs namely Content Knowledge (PK), Pedagogical Knowledge (PP) and Technology Knowledge (PT). The interaction of these three knowledges forms the other knowledge within the framework of the PTPK, namely Content Pedagogical Content (PPK), Pedagogical Technological Knowledge (PTP), Content Technological Knowledge (PTK) and Content Technological Knowledge Pedagogical Content (PTPK).

\section{The Importance Pedagogical Technological of Knowledge Content in Teaching the Malay Language}

Koehler, Mishra, \& Cain, (2013) defines technology knowledge as a wide range of technologies from low level such as pencil and paper, to digital technologies such as internet, interactive whiteboards, digital video, and program software. Furthermore, technology integration in teaching can enhance cooperative learning, curriculum integration, diversify learning strategies 
Vol. 8, No. 4, 2019, E-ISSN: 2226-6348 @ 2019 HRMARS

and styles, and improves teacher communication, community relations and global learning (Aguinaldo, 2017; Blackwell, Lauricella \& Wartella, 2016; Koehler \& Mishra, 2009; Whitehead, Jensen \& Boschee 2003; Bates, 2000). In the context of school education, the integration of technology in teaching will foster children's learning and facilitate teacher's teaching (Mourlam \& Herring 2016; Sandra, Bakr \& Norlidah, 2013).

Studies on mobile learning also have received much attention and debate from many researchers. Most studies are conducted at the tertiary and secondary levels, and more focused on perceptions (Hwang \& Tsai, 2011). Saipunidzam et al, (2012) conducted a study which focused on application design for teaching Malay Language, but the application still a temporary concept. While, study by Nuraihan and Zamnah (2012) showed that reading comprehension exercises delivered to mobile phones can improve student reading performance in Malay Language. The results of pre and post tests showed that overall student performance was better than others (Rosnani \& Mashila, 2017).

In addition to mobile learning facilities, the internet also allows users to access more reading material without needs to spend a lot of money to buy printed material. Access to unlimited information enables extensive reading. According to Tanaka \& Stapleton (2007), widespread reading refers to large numbers of casual language readings by focusing on quantity rather than quality. This means that the method focuses more on the meaning of language rather than on language (Tran, 2006). These activities can help to improve the vocabulary and structure of one's language (Shen, 2008).

Knowledge of pedagogy is an in-depth knowledge of the process of teaching or teaching and learning including the purpose and value of education (Harris et.al.2007). Shulman (1987) pedagogical knowledge refers to knowledge of teaching principles and methods which includes of classroom teaching and learning such as approaches, methods and techniques, strategies, curriculum and syllabus, testing and assessment, and recovery and enrichment. While Koehler and Mishra (2009) defined pedagogical knowledge about teaching methods and processes and involved the knowledge of classroom management, assessment, lesson plan development, and student learning environment.

Today's education demands that all teachers need to possess wide range of pedagogical knowledge, skills, and attitudes. Whoever entitled as a teacher needs to provide themselves with knowledge, positive personality and effective teaching methods or pedagogical skills to attract students to learn. Every teacher must experience the most difficult part of the learning and preparation process (PdPc). A successful and effective teacher is a teacher with deep expertise in the field or subject taught (Mahamod, 2014).

Mishra and Koehler (2006); and Bonner (2001) have stated that pedagogical knowledge is a belief and perception that influences the implementation of the curriculum, and reflects the teaching strategies used by teachers to implement the teaching. Teachers who do not have pedagogical knowledge may not be satisfied with their career because some of the factors that contribute to 
success teaching is depend on pedagogical knowledge (Padmavathi, 2017; Blackwell, Lauricella \& Wartella, 2016; Halim, 2014; Shatar, 2007; Schempp, Manross \& Tan, 1998). Therefore, teachers are said to be more comfortable and enthusiastic in teaching the students their specialty because able to tailor the pedagogical knowledge by the variety of students' abilities and interests in related subject or to teacher teaching (Shulman, 1986).

Shulman, (1986) also argued that content knowledge is an understanding of subject as a discipline. He explained that content knowledge is a knowledge structure that incorporates the theories, concepts, and principles of a learning discipline or subject. Theories, concepts and principles are different from the elementary learning discipline, or the discipline of mathematics subjects different from the language learning discipline. Therefore, to teach a subject, teachers need to have good and up-to-date content knowledge (Koehler, Greenhalgh, Rosenberg \& Keenan, 2017; Cherner \& Smith, 2016; Shatar, 2007; Yusminah, 2004;).

Besides, content knowledge is a construct which represents an element that describes the aspects of teacher's understanding on the teaching subject before translating it into a classroom teaching and learning activity (Muhammad Hafizan \& Anuar, 2017). Based on this statement, mastery of content knowledge also means that teachers need to master and have a good grasp of the topics to be taught before devising methods to present them to students (Hlas \& Hildebrandf, 2010) to ensure accuracy of facts and clarity of content delivered on objective builtin learning.

According to Norashilah et al. (2013); Yatin, Hamid, Shah, \& Hassan, (2018); Shbeilat, Al Harasees, (2018), the PCK approach requires teachers to deeply understand the concept of the subject's content which is taught. Shulman (1986) also emphasized that a teacher must clearly understand what he or she is teaching, and comprehend the reasons and facts behind what he or she is teaching. Teachers' understanding towards teaching knowledge areas is the most important aspect (Magdeline \& Zamri, 2014) in teaching and learning process because mastery of content knowledge is a reflection of how teacher influences the content of lesson in a way that students can easily understand (Hafizan \& Anuar, 2017; Mavridis, 2014).

Therefore, it can be concluded that content knowledge is the knowledge, information or mastery of the subject's content that he or she is teaching. The degree of mastery or depth of knowledge about the content of a subject is the most valuable and fundamental asset that every teacher in the teaching profession shall possess. The success of a teacher in producing quality teaching can be measured by the possessed content knowledge because the mastery level of content knowledge often distinguishes by the effectiveness of teaching although similar teaching methods and strategies are used.

Knowledge of Content Pedagogy Technology is a very important knowledge that requires all teachers to master it to teach effectively. This is because the content knowledge of pedagogical technology is often linked to the ability and effectiveness of teacher in delivering the teaching content to students, and can be comprehended easily. Furthermore, teaching reading skills will 
be fun, engaging, enhance student creativity and innovation, and stimulate student learning. This is similar to Mishra and Koehler's $(2006,2008)$ opinion who stated that content technology knowledge is a pedagogical understanding of technology assisted teaching and teaching effectiveness based on a good understanding of the content of the subject.

\section{Conclusion}

Teachers with high level of knowledge are asset to the country in fulfilling the Ministry of Education's desire to strengthen the national education system into world class education. By mastering the teacher pedagogical content technology will determine the quality of teaching and directly influence the outcome of teaching. It can be concluded that teachers who master the content of Content Pedagogy Technology will be able to teach reading skills more effectively as the government suggests compared to teachers who do not have content pedagogical technology. Teacher exploration in Technological Pedagogical Content Knowledge (TPCK) consists of Technology Knowledge (PT), Pedagogical Knowledge (PP), Content Knowledge (PK), Content Pedagogical Knowledge (PPK), Content of Technology Knowledge (PTK), and Pedagogical Technology Knowledge (PTP). These elements will contribute in enhancing teacher's creativity.

\section{Corresponding Author}

Musrifah Sarjoni

Faculty of Educational Studies,

University Putra Malaysia, 43400 UPM, Serdang, Selangor

Darul Ehsan, Malaysia.

srifah74@gmail.com

\section{References}

Ahmad, M. H. M. S. D. A. (2017). Pengaruh pengetahuan isi

kandungan terhadap aplikasi pengajaran yang berkesan dalam kalangan guruguru Sejarah. International Conference on Global Education V "Global Education, Common Wealth, and Cultural Diversity", 2457-2473.

Abbitt, J. T. (2011). Measuring Technological Pedagogical Content Knowledge in Preservice Teacher Education. Journal of Research on Technology in Education, 43(4), 281-300. https://doi.org/10.1080/15391523.2011.10782573

Aguinaldo, B. E. (2012). Developing and Applying TPACK for A Blended Learning Environment: A Rural Higher Education Experience In The Philiphines. The Countrside Development Reserach Journal, 1(1).

Atasoy, E., \& Aygun, B. (2016). Technological Pedagogical Content Knowledge of Prospective Mathematics Teachers Regarding Evaluation and Assessment. World Journal on Educational Technology, 8(1). https://doi.org/10.18844/wjet.v8i1.496

Beltramo, J., \& Stillman, J. (2015). Why Should Students Want to Do a Close Reading? Voices from the Middle, 22, 9-14.

Bonner, P. S. (2001). The influence of secondary science teachers' pedagogical content 
INTERNATIONAL JOURNAL OF ACADEMIC RESEARCH IN PROGRESSIVE EDUCATION AND

DEVELOPMENT

Vol. 8, No. 4, 2019, E-ISSN: 2226-6348 @ 2019 HRMARS

knowledge, educational beliefs and perceptions of the curriculum on implementation and science reform.

Cherner, T., \& Smith, D. (2017). Reconceptualizing TPACK to Meet the Needs of Twenty-FirstCentury Education. The New Educator, 13(4), 329-349. https://doi.org/10.1080/1547688X.2015.1063744

Eady, M. J., \& Lockyer, L. (2013). Tools for learning: Technology and Teaching Strategies. Quensland University of Technology, Australia, 1(1).

Hasniza, N. (2014). Pre-service teachers'TPACK and experience of ict integration in schools in Malaysia and New Zealand. Tesis PhD. University of Canterbury, New Zealand. (Tidak diterbitkan).

Halim, A. (2014). Amalan pedagogi guru permulaan. Tesis PhD. Universiti Sains Malaysia. (Tidak diterbitkan).

Hashweh, M. (2014). Encyclopedia of Educational Theory and Philosophy. Thousand Oaks, SAGE Publications, Inc. https://doi.org/10.4135/9781483346229 NV .

Hlas, A., \& Hildebrandf, S. (2010). Demonstrations of pedagogical content knowledge: Spanish Liberal Arts andSpanish Education majors'writing. L2 Journal, 2 (2010), 1- 22.

Hwang, Gwo-Jen \& Tsai, C. (2011) Research trends in mobile and ubiquitous learning: a review of publications in selected journals from 2001 to 2010, British Journal of Educational Technology, 42(4), pp. 65-70.

Kern, R. (2006). Perspectives on Technology in Learning and Teaching Languages. Tesol Quartely, 40(1), 183-210.

Koehler, M., \& Mishra, P. (2009). What Is Technological Pedagogical Content Knowledge? Contemporray Issues in Technology and Teacher Education, 9(1), 60-70.

Koehler, M., Mishra, P., \& Cain, W. (2013). What is Technological Pedagogical Content Knowledge (TPACK)? Journal of Education, 193, 13-19. https://doi.org/10.1177/002205741319300303

Koehler, M., Greenhalgh, S., Rosenberg, J., \& Keenan, S. (2017). What the tech is going on with teachers? Digital teaching portfolios? Using the TPACK framework to analyze teacher? Technological understanding. Journal of Technology and Teacher Education, 25(1), 31-59. Abstract retrieved from http://learntechlib.org/p/173346.

Magdeline, A. K., \& Zamri, M. (2014). Penterjemahan Pengetahuan Pedagogi Kandungan dalam Proses Tindakan Guru Bahasa Iban Baharu dan Berpengalaman Bukan Opsyen. Jurnal Pendidikan Malaysia, 39(1) (2014), 37-49.

Mahzan, A. (2003). Pendidikan literasi bahasa Melayu: Satu pendekatan bersepadu. Kuala Lumpur. Utusan Publications \& Distributors Sdn. Bhd.

Ministry of Education. (2015). Malaysia Education Blueprint. Putrajaya, Malaysia.

Mishra, P., \& Koehler, M. (2006). Technological Pedagogical Content Knowledge: A Framework for Teacher Knowledge. Teachers College REcord, 108, 1017-1054.

Mavridis, S. (2014). The Human Right to The City. Multilingual Academic Journal of Education and Social Sciences, 2(2), 114-133.

Nelson, S. (2019). Close Reading in the Urban Classroom : A Teacher's Introspection. Online Journal for Teacher Research, 21(1).

Noraini, N., Hani, M., Mahizer, H., Mohd, I., \& Norazilawati, A. (2013). Penggunaan Inovasi 
INTERNATIONAL JOURNAL OF ACADEMIC RESEARCH IN PROGRESSIVE EDUCATION AND

DEVELOPMENT

Vol. 8, No. 4, 2019, E-ISSN: 2226-6348 @ 2019 HRMARS

Teknologi Dalam Pengajaran : Cabaran Guru Dalam E-Pembelajaran. In Proceedings Of The 7 International Malaysianeducational Technology Convention (IMETC 2013). Golden Flower Hotel, Bandung, Indonesia, 16-18 September 2013.

Norhiza, F., Zamri, M., \& Razana, W. M. (2016). Competencies, Attitude and Application of Web 2.0 as a Teaching Aids among Malay Language Primary School Teachers. Jurnal Pendidikan Bahasa Melayu, 6(2), 52-58.

Norashilah, Z., Hasniza, N. I., Johari, S., Ellany, L. M., \& Farahwahidah, N. A. R. (2013). Amalan Pengetahuan Pedagogi Kandungan (PPK) Dalam Kalangan Pensyarah Kimia Universiti Teknologi Malaysia. 2 nd International Seminar on Quality and Affordable Education (ISQAE 2013), 154-165.

Daud, N. M. (2012). Young learners' use of ICT facilities and the development of their language skills, dalam Nuraihan Mat Daud (ed.) Technology and Foreign Language Learning and Teaching, IIUM Press: Kuala Lumpur. pp. 98-107.

Daud, N. M. (2012). Language Teachers' Web Surfing Skills: Teachers' knowledge of metaseacrh engines and advanced search facilities in Nuraihan Mat Daud (ed.) Technology and Foreign Language Learning and Teaching, IIUM Press: Kuala Lumpur. Pp. 1-11.

Ozudogru, M. (2019). Technological Pedagogical Content Knowledge of Mathematics Teachers and the Effect of Demographic Variables. Contemporary Educational Technology, 10(1), $1-24$.

Padmavathi, M. (2017). Preparing teachers for technology-based teaching-learning using TPACK. i-manager's Journal on School Educational Technology, 12(3), 1-9.

Papanikolaou, K., Makri, K., \& Roussos, P. (2017). Learning design as a vehicle for developing TPACK in blended teacher training on technology enhanced learning. International Journal of Educational Technology in Higher Education, 14(1), 34. https://doi.org/10.1186/s41239-017-0072-z

Rahman, A. S. C. A. (2007). Pengetahuan kandungan pedagogi guru Pendidikan Moral Tingkatan Empat di sebuah sekolah. Tesis PhD. Universiti Malaya. (Tidak diterbitkan).

Radha, M. N., Noorizah, M. N., Kemboja, I., \& Shahirah, A. (2017). New Learning Spaces and Transformations in Teacher Pedagogy and Student Learning Behavior in the Language Learning Classroom. Asian Journal of English Language Studies, 23(4), 29-40.

Rosnani, J., \& Mashila, N. I. (2017). Kajian Terhadap Pengajaran dan Pembelajaran Berasaskan Teknologi Kursus Pengurusan Perniagaan di Kolej Vokasional. International Journal of Education and Sciences, 1(1), 71-82.

Serravallo, J. (2015). Reading Strategies. (Z. R. White, Ed.) (First Edit). Heinemann, Portsmouth, NH: Greenword Publishing.

Schempp, P., Manross, D., \& Tan, S. (1998). Subject expertise and teachers'knowledge. Journal of Teaching in Physical Education. 17, HIm. 1-15.

Shen, M. (2008) EFL learners' responses to extensive reading: Survey and pedagogical applications. The Reading Matrics, 8(2), 111-122.

Shbeilat, M. K., Al Harasees, M. N. (2018). Do Listed Companies Need an IFRS Committee Beside Audit Committee? International Journal of Academic Research in Accounting, Finance and Management Sciences 8 (2): 8-18.

Tamam, T., Zamri, M., Rahimi, N. M. Y., \& Jamaluddin, B. (2010). Masalah Membaca Murid-murid 
Sekolah Rendah Kerajaan di Brunei Darussalam: Satu Kajian Kes. Jurnal Pendidikan Malaysia, 35(2), 77-85.

Tanaka, H., \& Stapleton, P. (2007) Increasing reading input in Japanese high school EFL classroom: An empirical study exploring the efficacy of extensive reading. The Reading Matrics, $7(1)$ 115-131.

Tran, A. (2006)Modified extensive reading for English language learners. Reading Improvement, $43(4), 173-178$.

Wong, S. H., \& Elzira, N. A. (2018). Teacher's Perspective On Coaching and mentoring of School Improvement Specialist Coaches Plus (SISC+). International Journal of Education Psychology and Counselling, 3(13), 57-72.

Whitehead, B. M., Jensen, D. F. N., \& Boschee, F. (2003). Planning for technology: A guide for school administrators, technology coordinators, and curriculum leaders. USA: Corwin Press.

Yahya, B., \& Lailinanita, A. (2012). Inovasi Pengajaran Dan Pembelajaran Dalam Kalangan GuruGuru Teknikal Di Sekolah Menengah Teknik Dari Perspektif Guru. Journal of Technical and Vocational \&Engineering Education, 6(June), 44-58.

Yahya, O., \& Maszuraimah, M. S. (2013). Aplikasi Strategi Kesedaran Metakognisi Semasa Membaca Teks Moden dan Klasik dalam Kalangan Murid Prauniversiti. Jurnal Pendidikan Bahasa Melayu, 3(Mei), 61-71.

Yusminah, M. Y. (2004). Pengetahuan pedagogikal isi kandungan guru dalam topik fungsi: Satu Kajian Kes. Tesis Sarjana. Universiti Kebangsaan Malaysia.

Yatin, S. F. M., Hamid, H. A., Shah, J. R. K. M., \& Hassan, Z. (2018). Digital Era: New Trends in Information Agencies. International Journal of Academic Research in Progressive Education and Development, 7(3), 150-160.

Zamri, M. (2014). Inovasi P\&P dalam pendidikan Bahasa Melayu. Cetakan Ketiga. Tanjung Malim: Penerbit Universiti Pendidikan Sultan Idris 